\title{
Improving the Basic Writing Skills of Grade 7 Learners in Filipino: An Action Research in Filipino Language
}

OPEN ACCESS

Manuscript ID:

EDU-2021-09033815

Volume: 9

Issue: 3

Month: June

Year: 2021

P-ISSN: 2320-2653

E-ISSN: 2582-1334

Received: 07.03.2021

Accepted: 24.04.2021

Published: 01.06.2021

Citation:

Cabigao, Joey Ramos.

"Improving the Basic

Writing Skills of Grade 7

Learners in Filipino: An

Action Research in Filipino

Language." Shanlax

International Journal of

Education, vol. 9, no. 3, 2021, pp. 67-71.

DOI:

https://doi.org/10.34293/ education.v9i3.3815

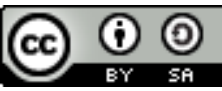

This work is licensed under a Creative Commons Attribution-ShareAlike 4.0 International License

\author{
Joey Ramos Cabigao \\ School Principal, Department of Education \\ Schools Division of City of Malolos, Region III, Philippines \\ https://orcid.org/0000-0002-8842-6828
}

\begin{abstract}
This action research primarily aims to remediate the low level of basic writing skills (writing in cursive, capitalization, punctuation, spelling, and paragraphing) of Grade 7 learners in Filipino class/subject in a government high school. The researcher conducted (1) assessment of learners' writing competency through pre and post-tests; (2) preparation/development of writing exercises; (3) activities are emphasizing the conduct of writing activities in and out of the classroom; and (4) home visitations to reinforce the teacher's and parents' monitoring on the progress of their children. A five-point rating scale was utilized in assessing learners' outputs. An increase of 1.56 was recorded in the general rating of pre to post-test, which shows that $80 \%$ improvement is manifested among the learners' basic writing competencies, proving that the intervention used is effective in achieving the target of the study. The study reveals the significant role of teachers in arousing learners' interest in writing and making them realize its importance. The study holds the importance of having learning activities and worksheets appropriate to the level of learners, needs to improve/enhance the unique skills in writing of each learner. Just like other researchers, this study encourages the promptly remediate the classroom-and school-based problems through the conduct of research for a rational and systematic way of addressing it. With the aid of well a documented study in all research endeavors, this will guide other teachers and school heads to experience the same plight of addressing the gaps in schools effectively.
\end{abstract}

Keywords: Basic writing skills, Writing mechanics, Learning gaps, Remediation, Writing activities

\section{Introduction}

Writing is such a complex skill (Badayos, 2008); thus, an individual needs necessary competencies to effective writing to come up with an acceptable output. Basics to writing are adherence to the 'writing mechanics', including writing form, spelling, punctuation, and writing conventions. The said basics of writing will serve as an important foundation for learners in effective written communication.

Upon graduation at the elementary level, learners are expected to write properly and with some creativity. Specifically, learners should have acquired the following writing competencies: (1) writing in cursive; (2) with correct forms and shapes of letters; (3) correct capitalization of letters; (4) correct punctuations; (5) and correct indentions and margins. All these competencies are clearly stated in the 2002 Basic Education Curriculum of the elementary years; the scope and sequence of competencies in Writing as Macro skill are shown in Table 1. Through these skills, learners can use written communication effectively and prepare themselves for the more complex forms of writing in the higher levels of the education ladder. 
Table 1: Learning Competencies on Writing as Macro skill in the 2002 Basic Education Curriculum

\begin{tabular}{|c|c|c|c|c|c|}
\hline Grade 1 & Grade 2 & Grade 3 & Grade 4 & Grade 5 & Grade 6 \\
\hline $\begin{array}{l}\text { Letters with } \\
\text { correct forms } \\
\text { and shapes }\end{array}$ & $\begin{array}{l}\text { Correct forms } \\
\text { and shapes of } \\
\text { letters }\end{array}$ & Capital letters & - & - & $\begin{array}{l}\text { Proper } \\
\text { punctuation }\end{array}$ \\
\hline Own name & $\begin{array}{l}\text { Correct spacing } \\
\text { of letters and } \\
\text { words }\end{array}$ & $\begin{array}{l}\text { Correct punctuation: } \\
\text { period, question mark, } \\
\text { and exclamation point }\end{array}$ & Comma & $\begin{array}{l}\text { Punctuation in } \\
\text { Sentences }\end{array}$ & \\
\hline \multirow[t]{2}{*}{$\begin{array}{l}\text { Capitalization in } \\
\text { the initial letter } \\
\text { of name/ days/ } \\
\text { sentences }\end{array}$} & Cursive writing & $\begin{array}{l}\text { Correct indention and } \\
\text { margin }\end{array}$ & $\begin{array}{l}\text { Comma in the } \\
\text { salutation and } \\
\text { complimentary } \\
\text { closing }\end{array}$ & $\begin{array}{l}\text { Use of parenthesis, } \\
\text { colon, semi-colon, } \\
\text { and hyphen }\end{array}$ & \\
\hline & $\begin{array}{l}\text { Short rhymes } \\
\text { Short paragraph }\end{array}$ & $\begin{array}{l}\text { Different kinds of } \\
\text { sentence }\end{array}$ & $\begin{array}{l}\text { Diary, } \\
\text { conversation, } \\
\text { and dialogue }\end{array}$ & $\begin{array}{l}\text { Short news, poster, } \\
\text { instructions, and } \\
\text { others }\end{array}$ & $\begin{array}{l}\text { Formal and } \\
\text { informal } \\
\text { composition }\end{array}$ \\
\hline
\end{tabular}

As learners enter Grade 7 of the high school curriculum, they are expected to manifest basic writing skills. Presented in Table 2 are the basic learning competencies in writing intended for the Grade 7 learners per $\mathrm{K}$ to 12 Basic Education Program Curriculum initially implemented for the School Year 2012-2013.

Table 2: Learning Competencies in Writing for Grade 7 in the $\mathrm{K}$ to 12 Basic Education Program Curriculum

\begin{tabular}{|c|c|c|c|}
\hline Quarter 1 & Quarter 2 & Quarter 3 & Quarter 4 \\
\hline $\begin{array}{l}\text { Determine the differences of } \\
\text { oral and written communication } \\
\text { focusing on each characteristic }\end{array}$ & $\begin{array}{l}\text { Write narrative } \\
\text { texts }\end{array}$ & $\begin{array}{l}\text { Write essay with } \\
\text { organization, coherence, } \\
\text { and unity ideas }\end{array}$ & Write paper review of a text \\
\hline $\begin{array}{l}\text { Write a simple and creative } \\
\text { description }\end{array}$ & & & $\begin{array}{l}\text { Effectively use the research } \\
\text { information in writing }\end{array}$ \\
\hline $\begin{array}{l}\text { Express emotion, idea, opinion, } \\
\text { and message using clear } \\
\text { sentences }\end{array}$ & & & \\
\hline $\begin{array}{l}\text { Write a simple and organized } \\
\text { paragraph }\end{array}$ & & & \\
\hline
\end{tabular}

The Department of Education believes that the competencies stated in Table 1 and 2 cannot be achieved if the existing learning gaps are not fully addressed through appropriate developmental or remediation activities (DepEd Order No. 39, series 2012); with this premise, this study came into.

\section{Conceptual Framework}

This study is anchored on the various principles of 'writing' as one of the five macro skills. According to Rivers (1975; as cited in Badayos, 1999), writing is an activity rooted in acquiring skills [skill-getting] until these skills are used in actual needs [skill-using]. In a modern perspective on writing, Liwanag (1999) noted that writing is a social process which indicates which we are using in our daily communication with others in different contexts or situation. She added that in writing, a need for critical analysis, interpretation, and communication of ideas based on one's previous experience and knowledge [schema] is a must for a successful writeup.

Teachers' role in writing plays an important part in the success of one's writing skills. According to Reid (1993), teachers are the key for the learners to acquire effective writing skills. Therefore, teachers must first acquire the skills themselves and develop instructional materials in teaching writing to effectively address the learning needs of the class. 
Badayos (2008) enumerated relevant premises that teachers can reflect on in developing effective writing skills among learners, and these are the following: (1) learners will only learn how to write well by reading good articles; (2) learners will only learn how to write well if they have enough time to write in and out of the classroom; (3) learners will only learn how to write well if they see that their teachers themselves write well; (4) learners will only learn how to write well if their teachers are creative and critical in assessing learner's writeup; (5) learners will only learn how to write well if they are not afraid to commit writing mistakes, and (6) learners will only learn how to write well if they realized that 'to read is to write' and 'to write to discover effective writing.'

Writing exercises were prepared based on the principles of Allwright and O'Neill (1990; as cited in Badayos, 1999). According to Allwright, an effective learning material helps learners learn the subject matter by opening the ideas presented in it with the assistance of their teachers. O'Neill reiterated that learning materials need to be developmentally appropriate to their target users to serve their purpose of development. The implementation of the intervention program of this study was documented carefully to capture the notable incidents that contribute to the improvement of the teachinglearning experience. The said program consisted of the development and utilization of writing exercises, integration of writing skills development in daily lessons, home visitations to select learners in need of close supervision, and consultation with parents/ guardians.

\section{The Objective of the Study}

This study primarily aims to bridge the learning gap of Grade 7 learners in their writing performance in Filipino subjects. To attain the main objective, the researcher: (1) assessed learners' writing competency through pre and post-tests; (2) prepared/developed writing exercises; (3) conducted learning activities emphasizing the conduct of writing activities in and out of the classroom; and (4) made home visitations to reinforce the teachers' and parents' monitoring on the progress of their children.

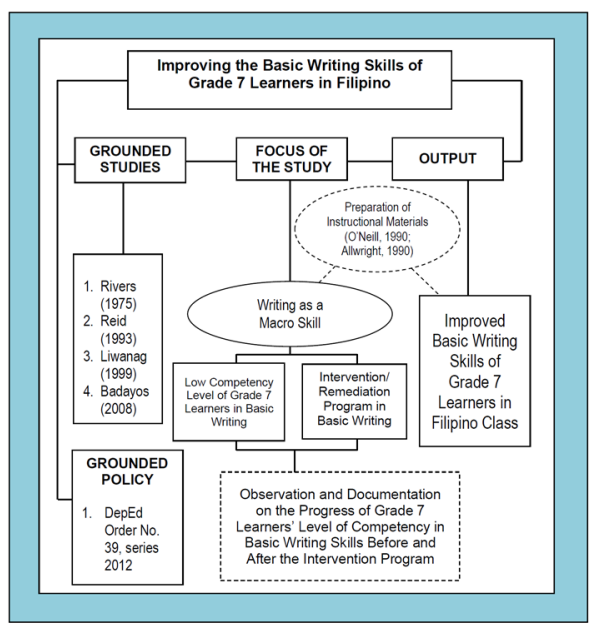

Diagram 1: Conceptual Model of the Study

\section{Methodology}

This action research is anchored on the principle of Nunan (1992) on language research which states that it undergoes a cycle with seven stages. The first stage is the conceptualization phase of the teacher as the key observer of the identified problem in the classroom. The second one is conducting an initial investigation through data gathering and observation in the classroom regarding learners' performance. The third stage involves the building of hypotheses or scientific guesses based on the pre-identified possible causes of the problems. The fourth stage deals with the preparation and implementation of the appropriate strategies or interventions that might address the problem. After which, the fifth stage goes, assessing the effectiveness of the strategies or interventions used; this can be done through observation or numerical data to quantify the improvement of learners' performance before and after the intervention. The sixth stage is the documentation of the program results, whether the intervention used marks positive or not so positive effects on the present condition. The final stage involves looking for possible alternative intervention programs even the implemented one is effective. This is to magnify the essence of language action research which is the continuous search for improving practice.

This study involved 75 Grade, 7 learners, using purposive sampling, with the following criteria: (1) they are under the classes of the researcher; 
(2) they will submit all the written exercises of the program, and (3) they will stay in school up to the end of the period of this study. The basic writing skills of the learners will be assessed using their written outputs and the assessment shall be based on the following: (1) writing in cursive; (2) capitalization; (3) punctuation; (4) spelling; and (5) paragraphing. The study covered the first semester of School Year 2012-2013, from June to October 2013.

\section{Results and Discussion}

In assessing learners' level of competency in writing, a five-point rating scale per DepEd Order No. 31, series 2012 was used as reference. At the beginning level, learners are still confused with themselves. They do not yet have basic skills needed for independent tasks, while on the developing level, learners now possess the basic skills yet still in need of close assistance in accomplishing tasks. In the approaching proficiency level, the necessary competencies are developed among learners, and through little assistance from teachers, the learners can apply what they have learned in accomplishing tasks. At the proficient level, learners can perform learning independently or without the guidance of their teacher. In the highest stage, advanced level, learners can surpass the basic competencies and now exemplifying automatic application of what they have learned in accomplishing given tasks.

Table 3: Table in Assessing Learners' Writing Skills

\begin{tabular}{|l|c|c|}
\hline \multicolumn{1}{|c|}{ Level of Competency } & Scale & Range \\
\hline Advanced (A) & 5 & $4.50-5.00$ \\
\hline Proficient (P) & 4 & $3.50-4.49$ \\
\hline Approaching Proficiency (AP) & 3 & $2.50-3.49$ \\
\hline Developing (D) & 2 & $1.50-2.49$ \\
\hline Beginning (B) & 1 & $1.0-1.49$ \\
\hline
\end{tabular}

The Preparation and Development of Writing Exercises

A compilation of writing exercises was prepared and developed per existing curriculum standards of the Department of Education. Supplementary activities were likewise added to address the identified learning gaps in terms of writing. The writing exercises and supplementary activities were subjected to peer validation of colleagues considered experts in such endeavors.

\section{The Administration of Writing Exercises}

Learners, little by little, underwent the intervention program with the usual flow of their class activities. Writing activities were given to them in a manner that they will enjoy it. Necessary preparatory activities were employed to set their mood ready for writing activities.

\section{The Home Visitations}

After having the pre-test results and during the intervention program, series of home visitation was conducted, especially to those learners who got the lowest scores. Conversations with their parents/guardians oriented the parents on how they can further monitor and assist their children in performing writing tasks to gain positive results.

\section{The Pre and Post-Tests Results}

Two sets of pre and post-tests were given to the learners to capture the progress of their performance in a wider perspective. The first set is writing information about oneself in a paragraph form, while the second one involves writing the differences of their characteristics from childhood to their present age. Both sets assessed their skills in cursive writing, capitalization, punctuation, and indention and neatness/legibility.

The appropriate writing remediation activities were given to the learners after administering the pre-test. The focus of the activities was on the writing mechanics to build among learners the basic skills of this important macro skill in language learning.

After the series of conducting intervention activities, an increase in the level of writing performance of the learners was recorded. From the overall mean of 1.96 (Developing) in the pre-test, it increased to 3.52 (Proficient) per post-test results. A difference of 1.56 increase was recorded, which showed $80 \%$ improvement in the basic writing skills of the learners. 
Table 4: Comparative Results of the Pre and Post-Tests

\begin{tabular}{|c|c|c|c|c|}
\hline & Pre-test & Level & Post-test & Level \\
\hline Part 1 & 2.23 & Developing & 3.49 & Approaching Proficiency \\
\hline Part 2 & 1.69 & Developing & 3.54 & Proficient \\
\hline Total & 1.96 & Developing & 3.52 & Proficient \\
\hline
\end{tabular}

\section{Conclusion}

The conduct of this study shed light on the following conclusions: (1) appropriately-developed writing activities or exercises are necessary for assisting learners in improving their basic writing skills; (2) learners can enjoy writing by giving them pre-activities to set their mood positively at the beginning of each writing activity; (3) home visitations can be used to seek parents support and assistance in monitoring the progress of their children in writing tasks; and (4) conducting writing intervention program can improved learners' basic writing skills, thus, bridging the identified learning gap.

\section{Recommendation}

From the findings and conclusions presented, the following recommendations are humbly presented: (1) schools shall continuously develop writing materials or exercises based on the actual needs of the learners through write shops; (2) teachers shall be reoriented on the importance of appropriate teaching strategies in writing through training/seminars to capture the interest and attention of the learners, thus maximizing the teaching-learning engagement; (3) parents/guardians shall be continuously updated on their roles in the monitoring and assisting of their children's progress during parent-teacher conferences; and (4) teachers shall regularly identify the needs of the learners to address their learning gaps in writing through positive effective intervention programs.

\section{References}

2001 Revisyon ng Alfabeto at Patnubay sa Ispeling ng Wikang Filipino. Commission on the Filipino Language, 2001.

Badayos, Paquito B. Metodolohiya sa Pagtuturo at Pagkatuto ng/sa Filipino: Mga Teorya, Simulain, at Istratehiya. Mutya Publishing House, 2008.

Badayos, Paquito B. Metodolohiya sa Pagtuturo ng Wika: Mga Teorya, Simulain at Istratehiya. Grandwater Publications and Research Corporations, 1999.

Diksiyonaryong Sentinyal ng Wikang Filipino. Commission on the Filipino Language, 2001.

Legaspi, Leonida Q. Mga Gawain sa Paglinang ng Kasanayan sa Pagsulat sa Ikaapat na Baitang sa Elementarya. Philippine Normal University, 2005.

Liwanag, Lydia B. Magkakangnay na Pagtuturo ng Pagbasa at Pagsulat sa Filipino: Mga Pananaw at Gawain. Phoenix Publishing House, 1999.

Nunan, David. Research Methods in Language Learning. Cambridge University Press, 1992.

Policy Guidelines on Addressing Learning Gaps and Implementing a Reading and Writing Program in Secondary Schools Effective School Year (SY) 2012-2013. DepEd Order No. 39, series 2012.

Policy Guidelines on the Implementation of Grades 1 to 10 of the $K$ to 12 Basic Education Curriculum (BEC) Effective School Year 2012-2013. DepEd Order No. 31, series 2012.

Reid, Joy M. Teaching ESL Writing. Prentice Hall, 1993.

\section{Author Details}

Joey Ramos Cabigao, School Principal, Department of Education, Schools Division of City of Malolos, Region III, Philippines, Email ID: joeycabigao@gmail.com 